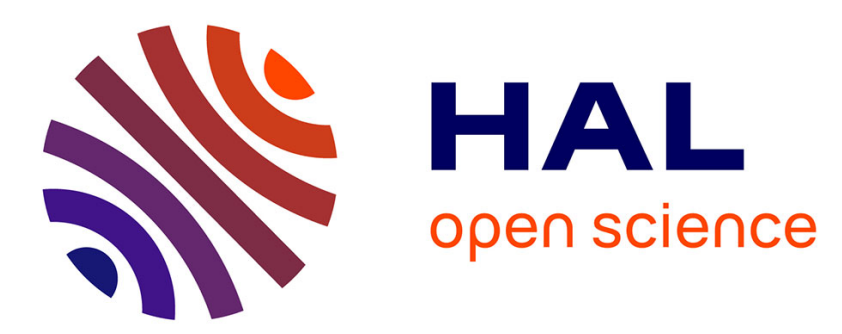

\title{
Hepcidin gene expression induced in the developmental stages of fish upon exposure to Benzo[a]pyrene (BaP)
}

Ke-Jian Wang, Jun Bo, Ming Yang, Hua-Sheng Hong, Xin-Hong Wang, Fang-Yi Chen, Jian-Jun Yuan

\section{- To cite this version:}

Ke-Jian Wang, Jun Bo, Ming Yang, Hua-Sheng Hong, Xin-Hong Wang, et al.. Hepcidin gene expression induced in the developmental stages of fish upon exposure to Benzo[a]pyrene (BaP). Marine Environmental Research, 2009, 67 (3), pp.159. 10.1016/j.marenvres.2008.12.008 . hal-00563066

\section{HAL Id: hal-00563066 https://hal.science/hal-00563066}

Submitted on 4 Feb 2011

HAL is a multi-disciplinary open access archive for the deposit and dissemination of scientific research documents, whether they are published or not. The documents may come from teaching and research institutions in France or abroad, or from public or private research centers.
L'archive ouverte pluridisciplinaire HAL, est destinée au dépôt et à la diffusion de documents scientifiques de niveau recherche, publiés ou non, émanant des établissements d'enseignement et de recherche français ou étrangers, des laboratoires publics ou privés. 


\section{Accepted Manuscript}

Hepcidin gene expression induced in the developmental stages of fish upon exposure to Benzo[a]pyrene (BaP)

Ke-Jian Wang, Jun Bo, Ming Yang, Hua-Sheng Hong, Xin-Hong Wang, FangYi Chen, Jian-Jun Yuan

PII:

S0141-1136(08)00263-8

DOI:

10.1016/j.marenvres.2008.12.008

Reference:

MERE 3312

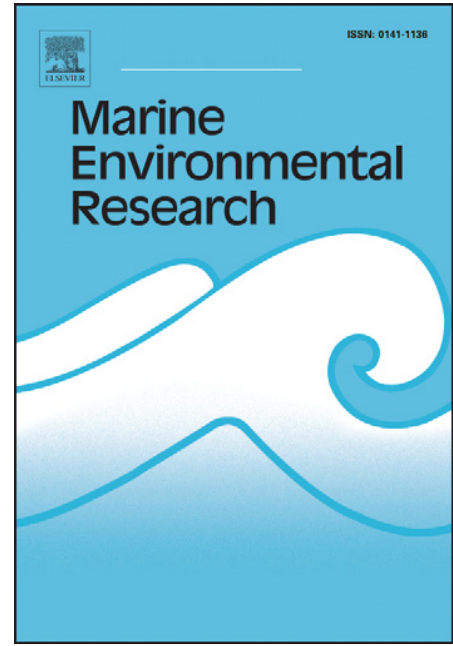

To appear in:

Marine Environmental Research

Received Date:

2 June 2008

Revised Date:

10 October 2008

Accepted Date:

23 December 2008

Please cite this article as: Wang, K-J., Bo, J., Yang, M., Hong, H-S., Wang, X-H., Chen, F-Y., Yuan, J-J., Hepcidin gene expression induced in the developmental stages of fish upon exposure to Benzo[a]pyrene (BaP), Marine Environmental Research (2008), doi: 10.1016/j.marenvres.2008.12.008

This is a PDF file of an unedited manuscript that has been accepted for publication. As a service to our customers we are providing this early version of the manuscript. The manuscript will undergo copyediting, typesetting, and review of the resulting proof before it is published in its final form. Please note that during the production process errors may be discovered which could affect the content, and all legal disclaimers that apply to the journal pertain. 


\section{Hepcidin gene expression induced in the developmental}

\section{stages of fish upon exposure to Benzo[a]pyrene (BaP)}

Ke-Jian Wang*, Jun Bo, Ming Yang, Hua-Sheng Hong, Xin-Hong Wang, Fang-Yi Chen,

Jian-Jun Yuan

State Key Laboratory of Marine Environmental Science, College of Oceanography and Environmental Science, Xiamen University, Xiamen, Fujian 361005, China

\section{Abstract}

Hepcidin is known to be expressed in fish with bacterial challenge and iron overload. Here we first report the hepcidin expression induced in the developmental stages from embryo to fry of red sea bream (Pagarus major) and in juvenile black porgy (Acanthopagrus schlegelii B.) upon continuous waterborne exposure to $\mathrm{BaP}$. The gene expression of CYP1A1 and IgL (immunoglobulin light chain) were both measured. Expression of the Pagarus major hepcidin gene (PM-hepc) was increased in post hatch fry at $24 \mathrm{~h}$ and $120 \mathrm{~h}$ exposure to $\mathrm{BaP}$ at concentrations of $0.1 \mu \mathrm{g} / \mathrm{L}, 0.5 \mu \mathrm{g} / \mathrm{L}$ and $1.0 \mu \mathrm{g} / \mathrm{L}$, respectively. The gene expression pattern was comparable to that of CYP1A1 but different from that of IgL. In addition, a high number of AS-hepc2 transcripts (Acanthopagrus schlegelii B. hepcidin gene) were detected in the

* Corresponding author. Tel.: +86 592 2184658, fax: +86 5922180655 .

E-mail address: wkjian@xmu.edu.cn (K.-J. Wang). 
16 liver upon exposure to $1.0 \mu \mathrm{g} / \mathrm{L} \mathrm{BaP}$. This study demonstrates that hepcidin gene expression is significantly induced in BaP-exposed red sea bream and black porgy.

Keywords: Fishes; Hepcidin; Benzo[a]pyrene; mRNA expression

\section{Introduction}

carcinogenic and immunotoxic properties (White et al., 1986; Davila et al., 1996). It is known from mammalian studies that the immune system is sensitive to the effects of pollution and several in vivo and in vitro studies have indicated that $\mathrm{BaP}$ induces immune alterations in fishes (Faisal and Huggett, 1993; Holladay et al., 1998; Smith et al., 1999). A single BaP injection significantly compromises the immune function and the host resistance against infection of Japanese medaka (Carlson et al., 2002).

The major molecular mechanism of BaP-induced immunotoxicity in fish appears to involve Aryl hydrocarbon receptor (AhR) induction of cytochrome P4501A1 (CYP1A1)-mediated metabolism of BaP (Carlson et al., 2002). The early life stages in fish development appear to be particularly sensitive to anthropogenic contaminants (Buhl and Hamilton, 1991). Furthermore, the embryonic, larval and

31 juvenile stages of both marine and fresh-water species may be affected by polynuclear aromatic hydrocarbons (PAHs) (Goksøeyr et al., 1991). Since the immune system is responsible for the defense of the host against infectious pathogens and any fluctuation in the immune response could potentially affect resistance of fish to diseases, measurements of immune status may predict fish health at-risk populations and indicate the impact of PAHs on fish farming.

Hepcidin was first found during studies of the antimicrobial peptides in human body fluids such as blood ultrafiltrate (Krause et al., 2000) and human urine (Park et al., 2001). The antimicrobial peptide hepcidin genes have been identified from various vertebrates including fish in recent years. Fish hepcidins possess antibacterial activity in vitro and their expression in the liver is dramatically induced 
41 indicating that besides their innate role in immune systems, some fish hepcidins exhibit functions other

42 than antimicrobial activity. In a complex marine environment, whether hepcidin gene expression would

43 be affected by environmental pollutants such as $\mathrm{BaP}$ has so far not been reported. In recent years, studies

44 on gene expression responses in mammals and fishes exposed to environmental pollutants have been

45 carried out, for example, some studies concerning on AhR-dependent or -independent 2,3,7,8-

46 tetrachlorodibenzo-p-dioxin (TCDD)-responsive genes (Puga et al., 2000; Frueh et al., 2001; Kurachi et

47 al., 2002; Adachi et al., 2004; Volz et al., 2005). Organ-specific gene expression responses were

48 revealed in male Japanese medaka (Oryzias latipes) exposed to TCDD (Volz et al., 2005). In addition,

49 the higher transcript of a hepcidin-like precursor in medaka liver was detected based on cDNA array

50 analysis, which was likely related to acute-phase responses associated with host defense and

51 inflammation (Volz et al., 2005). Although profiling multiple gene expression has been reported in

52 different fishes for identifying the toxic effects upon exposure to environmental contaminants (Larkin et

53 al., 2003; Denslow et al., 2004; Filby et al., 2007), no study has so far focused on the interesting

54 phenomenon that hepcidin mRNA expression could be induced upon exposure to environmental

55 pollutants. This study aims to investigate the relationship between organic pollutant exposure and

56 hepcidin gene expression in the developmental stages from embryo to fry of red sea bream and in

57 juvenile black porgy. The study will lead us to further explore in future whether the gene expression

58 alteration induced by $\mathrm{BaP}$ will affect the functions of fish hepcidin.

\section{Materials and methods}

61 2.1. Materials

$62 \mathrm{BaP}$ was purchased from Sigma (HPLC grade, USA) and was dissolved in acetone. All other

63 chemicals were reagent grade and obtained from local commercial sources.

\section{2.2. Experiment design}

65 2.2.1. Waterborne exposure of embryos, fry of red sea bream and juvenile black porgy to BaP 
Fertilized eggs of the red sea bream (Pagarus major) were obtained from the Fisheries Research

Institute of Fujian Province. At the early embryonic developmental stage, groups of approximately 2000 healthy embryos were exposed to acetone $\left(\mathrm{V}_{\text {acetone }} / \mathrm{V}_{\text {seawater }}=1 / 20000\right)$ or environmental relevant concentrations of $\operatorname{BaP}(0.1,0.5,1.0 \mu \mathrm{g} / \mathrm{L})$ after $8 \mathrm{~h}$ post fertilization (hpf). Embryos were maintained in 60L aquaria of sand-filtered inshore seawater with the following characteristics: dissolved oxygen about $8.0 \mathrm{mg} / \mathrm{L}$; pH 7.6; and 30\%o salinity. Other experimental conditions involved: daily renewal of the test medium; a constant temperature of $20^{\circ} \mathrm{C}$; and $10: 14 \mathrm{~h}$ light:dark conditions. The test comprised one control and the three toxicant concentrations, with three replicates of each concentration. The experiment was designed to reveal the hepcidin mRNA, CYP1A1 mRNA and IgL mRNA expression alterations in the developmental stages from embryo to fry of red sea bream. Briefly, after $48 \mathrm{~h}$ exposure to $\mathrm{BaP}$ post fertilization, continued to be exposed to $\mathrm{BaP}$ over the course of the experiment. Samples were taken at different times ( $8 \mathrm{hpf}, 48 \mathrm{hpf}, 24 \mathrm{~h}$ post hatch (hph), $72 \mathrm{hph}$ and $120 \mathrm{hph})$, and approximately 100 embryos or fry per treatment were sampled, immediately frozen in liquid nitrogen and stored at $-80^{\circ} \mathrm{C}$. To assess whether expression of hepcidin, CYP1A1 and IgL mRNAs is induced by the $\mathrm{BaP}$, controls (unexposed fish) were in parallel set up for each time point at which samples of exposed fish are taken.

Juvenile black porgy (50-70 g, body length 12-14 cm, male) were obtained from a fish farm (TongAn marine-culture farm) in Xiamen, Fujian province, China. Fish were reared in seawater tanks in the laboratory at room temperature $\left(21 \pm 1^{\circ} \mathrm{C}\right)$ for seven days for acclimatization prior to the start of the experiment, and fed with commercial pellets at $1 \%$ of body weight daily during this period. Healthy fish were chosen for the toxicological experiment. The experiment was designed as follows: the control group without adding $\mathrm{BaP}$; $\mathrm{BaP}$-exposed groups with a concentration of $1 \mu \mathrm{g} / \mathrm{L}$; the solvent control $\left(\mathrm{V}_{\text {acetone }} / \mathrm{V}_{\text {seawater }}=1 / 20000\right)$. The test solution was renewed daily and during exposure period the fish were not fed. Samples were collected after $0 \mathrm{~h}, 6 \mathrm{~h}, 24 \mathrm{~h}$ and $48 \mathrm{~h}$ exposure to BaP. Three fish from each group were taken at each exposure time point. Samples of liver, gill, spleen, kidney, stomach and 
91 intestine from each individual fish were separately collected. Samples were immediately frozen in liquid

92 nitrogen and stored at $-80^{\circ} \mathrm{C}$.

93 2.2.2. Quantitative real-time PCR analysis of gene expression of hepcidin, CYP1A1 and IgL

94 Cloning of CYP1A1 cDNA The red sea bream CYP1A1 cDNA sequence (GenBank accession no.

$95 \underline{\text { EU163982}}$ ) and the black porgy CYP1A1 cDNA sequence (GenBank accession no. DQ898145) were

96 both amplified from liver RNA with RT-PCR. Specific primers and probes for analyzing CYP1A1

97 mRNA expression in red sea bream and black porgy using quantitative real-time PCR were designed

98 based on a 69bp sequence (Table 1), and showed that more than $95.6 \%$ of the amino acids were identical

99 between red sea bream CYP1A1 and black porgy CYP1A1 cDNA. The 5'-

100 CTTCCGCCACATTGTCGTCTCCG-3' probe for hybridization was designed based on the red sea

101 bream CYP1A1 cDNA sequence, which completely matched the corresponding sequence of black

102 porgy.

103 Cloning of hepcidin cDNA An AS-hepc2 (Acanthopagrus schlegelii B. hepcidin gene) cDNA 104 sequence of black porgy was reported previously (Yang et al., 2007) and that of red sea bream (PM-hepc) 105 was amplified in our laboratory and released on GenBank (GenBank accession no. $\underline{\text { AY557619)}}$. The AS106 hepc2 gene was one of seven hepcidin variants previously identified in black porgy for which gene 107 expression in different tissues of this animal challenged with bacteria was evaluated using real-time 108 PCR. Specific primers and probes for analyzing hepcidin mRNA expression in red sea bream and black 109 porgy using real-time PCR were designed based on a 93 bp sequence, and more than $95.6 \%$ of the amino 110 acids were identical between PM-hepc and AS-hepc2 cDNA. The 5'-

111 CCCTGCTGGCTGTCGCTTTTGC- 3' probe for hybridization was designed based on the PM-hepc 112 cDNA sequence, which showed completely identical amino acids to the corresponding sequence of AS113 hepc2.

114 Primers and probes designed for analyzing IgL transcripts A pair of primers and a probe were 115 designed (Table 1) for real-time PCR in order to examine the IgL mRNA expression changes according 116 to the IgL cDNA sequence of red sea bream released on GenBank ( $\underline{\mathbf{A Y 1 9 0 7 0 6}})$. Total RNA of embryos 
and fry of red sea bream were isolated from a pool of over 100 embryos or fry using the TRIzol method

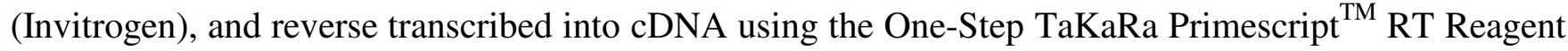
Kit (Perfect Real-time, DRR037S, TaKaRa). The procedure followed as described in Yang et al. (2007).

Quantitative real-time PCR analysis of gene expression To evaluate the influence of BaP exposure on the hepcidin mRNA expression of red sea bream and black porgy, a real-time PCR approach was developed. Real-time PCR assays were performed using the Taqman probe methodology and an ABI 7500 System (Applied Biosystems). Gene-specific primers (Table 1) were designed with the Primer Express(r) Software v3.0 (Applied Biosystem). The housekeeping gene for 18S rRNA was used as the endogenous assay control and the $18 \mathrm{~S}$ rRNA transcript maintained stable under the treatments analyzed by semi-quantitative PCR (data were not shown). The reactions were performed in a $25 \mu \mathrm{L}$ mixture containing 12.5 $\mu \mathrm{L}$ Taqman Universal PCR Master Mix (ABI), 500 nM primers, 200 nM Probes and $1 \mu \mathrm{L}$ cDNA, and the real-time RT-PCR reactions were performed in triplicate for each cDNA sample. Thermocycling was conducted as follows: $50^{\circ} \mathrm{C}$ for $2 \mathrm{~min}$ followed by $10 \mathrm{~min}$ incubation at $95^{\circ} \mathrm{C}$; then 40 temperature cycles $\left(95^{\circ} \mathrm{C}, 30 \mathrm{~s} ; 60^{\circ} \mathrm{C}, 60 \mathrm{~s}\right)$. The relative expression levels (fold induction) of the tested genes, were calculated using the relative expression software tool (ABI), based on the $2^{-\Delta \Delta C T}$ relative response method (Livak and Schmittgen, 2001). Meanwhile, the CYP1A1 and IgL mRNA expressions were in parallel measured following the same procedure. The CYP1A1 mRNA expression was measured here as an indicator showing P4501A1 involved in BaP metabolism.

\subsubsection{Measurement of accumulative concentrations in black porgy}

The accumulative concentrations were measured in the liver of juvenile black porgy upon exposure to $1 \mu \mathrm{g} / \mathrm{L} \mathrm{BaP}$ and the procedure was performed following the method of Del Castillo et al. (1992).

\subsubsection{Statistical analysis}

Results are presented as mean \pm SD. Each data was analyzed from three fish for each time point and all experiments were performed three times. The levels of statistical significance were analyzed by oneway ANOVA using SPSS 11.5 version, and results were considered to be significant when $p<0.05$. 


\section{Results}

3.1. CYP1A1 mRNA expression in the developmental stages from embryo to fry of red sea bream

As shown in Fig. 1a, CYP1A1 expression increased 4-fold over controls in embryos after a $48 \mathrm{~h}$ exposure to $0.1 \mu \mathrm{g} / \mathrm{L} \mathrm{BaP}$. Increasing the dosage to 0.5 or $1.0 \mu \mathrm{g} / \mathrm{L}$ did not cause any further increse. A slight rise of CYP1A1 expression level was found in the fry stage after $24 \mathrm{~h}$ exposure to all three doses of $\mathrm{BaP}$ and was significantly increased (by 6-fold) at the $1.0 \mu \mathrm{g} / \mathrm{L}$ dose (Fig. 1b). However, no significant change was observed after $72 \mathrm{~h}$ exposure to 0.1 and $0.5 \mu \mathrm{g} / \mathrm{L} \mathrm{BaP}$, while a slight alteration $(<$ 3-fold) was detected at the $1.0 \mu \mathrm{g} / \mathrm{L}$ dose. The mRNA expression of CYP1A1 was induced markedly after $120 \mathrm{~h}$ exposure to all three doses of BaP. The increased level could reach 10-fold that of the control. The result demonstrated that, after $120 \mathrm{~h}$, the CYP1A1 expression could be induced to a much higher level in the fry phase of red sea bream exposed to each of the doses tested compared to normal healthy fish (Fig. 1b). The control, albeit low, was also measurable in all the developmental stages examined.

\subsection{Hepcidin mRNA expression in the developmental stages from embryo to fry of red sea bream} exposed to BaP

To determine whether hepcidin expression in red sea bream was induced upon exposure to BaP, expression of PM-hepc mRNA in the developmental stages from embryo to fry of red sea bream during different periods of exposure to $\mathrm{BaP}$ at three doses $(0.1 \mu \mathrm{g} / \mathrm{L}, 0.5 \mu \mathrm{g} / \mathrm{L}$ and $1.0 \mu \mathrm{g} / \mathrm{L})$ was determined by quantitative real-time PCR. As shown in Fig. 2b, PM-hepc transcripts were observed during the fry phase of red sea bream exposed to the three doses of BaP. A higher than 9-fold increase in PM-hepc expression was seen in fry after $24 \mathrm{~h}$ exposure to $1.0 \mu \mathrm{g} / \mathrm{L} \mathrm{BaP}$, and roughly a 3-fold increase was detected after $24 \mathrm{~h}$ exposure to either $0.1 \mu \mathrm{g} / \mathrm{L}$ or $0.5 \mu \mathrm{g} / \mathrm{L}$ BaP. A marked increase in PM-hepc mRNA 
and 6-fold higher than the control at a dose of $1.0 \mu \mathrm{g} / \mathrm{L}$ BaP. However, no significant alteration in PMhepc transcript expression was discerned in fry after $72 \mathrm{~h}$ exposure to the three experimental doses of $\mathrm{BaP}$ in comparison with the control. The PM-hepc expression pattern in the developmental stages from embryo to fry of red sea bream induced by $\mathrm{BaP}$ at the tested doses appear to be comparable to the CYP1A1 mRNA expression (Fig. 3). In addition, it was found that PM-hepc transcripts were decreased at $48 \mathrm{hpf}$ when embryos were exposed to three concentrations of BaP (Fig. 2a). Correspondingly, CYP1A1 transcripts were also decreased (Fig. 3).

\subsection{IgL mRNA expression in the developmental stages from embryo to fry of red sea bream} exposed to BaP

For comparison with the alteration of hepcidin transcript expression in red sea bream exposed to BaP, we set up a parallel trial to examine IgL mRNA expression change during the period of exposure to BaP in order to look for a difference in the gene expression pattern between an innate immune-related gene (hepcidin) and an adaptive immune-related gene ( $\operatorname{IgL})$. $\operatorname{IgL}$ mRNA expression alteration in the developmental stages from embryo to fry of red sea bream during the course of exposure to three BaP doses, $0.1 \mu \mathrm{g} / \mathrm{L}, 0.5 \mu \mathrm{g} / \mathrm{L}$ and $1.0 \mu \mathrm{g} / \mathrm{L}$, was analyzed using quantitative real-time PCR. IgL mRNA expression was not altered $48 \mathrm{hpf}$ and showed no response in the fry 24 and $72 \mathrm{hph}$ upon exposure to doses of $0.1 \mu \mathrm{g} / \mathrm{L}, 0.5 \mu \mathrm{g} / \mathrm{L}$ and $1.0 \mu \mathrm{g} / \mathrm{L} \mathrm{BaP}$. An increase of $\operatorname{IgL}$ expression was detected only in fry after $120 \mathrm{~h}$ exposure. At the time, higher than roughly 50 -fold and 20 -fold $\mathrm{IgL}$ expression was seen in fry exposed to $0.1 \mu \mathrm{g} / \mathrm{L}$ and $0.5 \mu \mathrm{g} / \mathrm{L}$ BaP, respectively. Particularly, a high level of IgL mRNA expression (rising to 414-fold the control) was detected in fry $120 \mathrm{hph}$ upon exposure to $1.0 \mu \mathrm{g} / \mathrm{L} \mathrm{BaP}$.

\subsection{CYP1A1 mRNA and AS-hepc2 mRNA expression in multiple tissues of juvenile black porgy}

\section{upon exposure to BaP}

The levels of CYP1A1 mRNA expression in various tissues of juvenile black porgy were assessed using quantitative real-time PCR in BaP-exposed fish. Samples included liver, stomach, intestine, 
kidney, gill and spleen were individually collected from the tested fish after $0 \mathrm{~h}, 6 \mathrm{~h}$ and $48 \mathrm{~h}$ exposure to a concentration of $1 \mu \mathrm{g} / \mathrm{L} \mathrm{BaP}$. No significant change of CYP1A1 expression was detected in the liver, kidney and gill after $6 \mathrm{~h}$ exposure to $\mathrm{BaP}$ compared with the control (Fig. 4). CYP1A1 transcript expression was markedly induced after $48 \mathrm{~h}$ and increased to a higher level in the liver, kidney and gill. The expression level for these tissues was increased to 115-fold, 131-fold and 96-fold the control level, respectively (Fig. 4). Additionally, the CYP1A1 mRNA expression was induced in the intestine at $6 \mathrm{~h}$ exposure to $\mathrm{BaP}$, and significantly increased at $48 \mathrm{~h}$ exposure (Fig. 4). Meanwhile, rise of CYP 1A1 expression was also observed in the stomach after $6 \mathrm{~h}$ and $48 \mathrm{~h}$ and in the spleen after $48 \mathrm{~h}$ exposure to $\mathrm{BaP}$ (Fig. 4).

Although the data for CYP1A1 expression analysis from the samples exposed to BaP at $24 \mathrm{~h}$ missed due to RNA contamination, this may not influence the assessment on BaP altering AS-hepc2 gene expression. As described above, the CYP1A1 mRNA expression was measured here as an indicator showing P4501A1 involved in BaP metabolism. Even though missing the result of CYP1A1 mRNA expression at $24 \mathrm{~h}$ exposure to $\mathrm{BaP}$, the data at $6 \mathrm{~h}$ and $48 \mathrm{~h}$ shown in Figure 4 still clearly indicates BaP metabolism in juvenile black porgy.

AS-hepc 2 mRNA expression in various tissues of juvenile black porgy was analyzed using real-time PCR after 0 h, 6 h, $24 \mathrm{~h}$ and 48 h exposure to BaP. A high amount of AS-hepc2 transcripts was detected in the liver upon exposure to $\mathrm{BaP}$ at a dose of $1.0 \mu \mathrm{g} / \mathrm{L}$, the level increased to 350,22 , and 4838 -fold after 6, 24, and $48 \mathrm{~h}$, respectively (Fig. 5). In particular, the hepatic AS-hepc2 expression level was highly induced (4838-fold) in juvenile black porgy exposed to BaP.

To look for whether there is a relationship between the hepatic accumulative BaP concentration and AS-hepc2 gene expression, a preliminary experiment was carried out to investigate a BaP-accumulating trend in the liver of juvenile black porgy during the period of exposure to BaP. The result showed that the accumulative $\mathrm{BaP}$ concentration in the liver changed with exposure time and reached its highest level $48 \mathrm{~h}$ after exposure to $1 \mu \mathrm{g} / \mathrm{L}$ Bap (Fig. 6). Interestingly, the AS-hepc2 mRNA was highly expressed in the liver upon exposure to $\mathrm{BaP}$ at $48 \mathrm{~h}$ when $\mathrm{BaP}$ concentration in the liver was 
221 accumulating up to its highest level. It seems that AS-hepc2 mRNA expression increased with the

222 hepatic accumulative BaP concentration and exposure time as observed in Fig. 5 and Fig. 6.

\section{Discussion}

In this study, the effects of BaP on the gene expression of the antimicrobial peptide PM-hepc in red

sea bream and AS-hepc2 in black porgy were investigated using quantitative real-time PCR. It was

found that PM-hepc gene expression was markedly induced in the fry stage of red sea bream and AS-

hepc2 in juvenile black porgy exposed to $0.5 \mu \mathrm{g} / \mathrm{L}$ and $1.0 \mu \mathrm{g} / \mathrm{L} \mathrm{BaP}$ respectively. This is a very

interesting observation to date on hepcidin expression in fishes exposed to BaP. In China, many

commercial fish species, including red sea bream and black porgy, were raised in coastal waters, which

probably have been polluted with various persistent organic pollutants such as PAHs for a long time

(Maskaoui et al., 2002). These coastally raised fishes may be exposed to various microorganisms and

toxic pollutants daily, but still maintain a sufficiently healthy status to be able to grow causes us to

speculate whether some fish antimicrobial peptides such as hepcidin might function in the regulation of

these environmental pollutants as it did in the regulation of bacterial challenge. However, at present,

there is no direct evidence to support this presumption. To investigate this presumption, the induction of

hepcidin expression was investigated in red sea bream and black porgy upon exposure to an

experimental BaP. Our studies clearly demonstrated that the target hepcidin gene (PM-hepc and AS-

hepc2) expression in BaP-exposed fishes was significantly induced in the developmental stages and the expression pattern was to some extent associated with P450 1A1 metabolism (Fig. 3).

The liver is considered as the main organ for CYP mediated biotransformation in fishes (Stegeman and Kloepper-Sams, 1987). Also, CYP1A induction has been measured in other tissues, including those contacting directly with the environment, such as gills (Miller et al., 1989), intestine (Van Veld et al., 1990), kidney (Wolkers et al., 1998), and so on. The change of CYP1A expression in fish tissues is frequently used as an indicator of exposure to PAHs or PCB contaminants (Stegeman et al., 2001; Miller 
levels were roughly 115-fold, 131-fold and 96-fold higher in the liver, kidney and gill, respectively, after $48 \mathrm{~h}$ exposure to a concentration of $1.0 \mu \mathrm{g} / \mathrm{L} \mathrm{BaP}$ (Fig. 4), demonstrating that there were significant organ-dependent differences in CYP1A1 transcript levels at this sampling time and dose. Significantly higher levels of CYP1A1 transcript detected in exposed juvenile black porgy in this study supported 251 liver and other tissues exposure to BaP. It is also noteworthy that the high induction of CYP1A1 in the 252 kidney of juvenile black porgy was in accord with previous studies (Wolkers et al., 1998), suggesting 253 that the kidney may possibly be involved in contaminant-related induction of CYP1A1. The role of the kidney as an extra-hepatic tissue in xenobiotic metabolism might contribute to the biotransformation of PAHs (Kennedy and Walsh, 1994; Van Veld et al., 1997). The interesting work is left to be further investigated. In comparison with the CYP1A1 expression results (Fig. 4), we found that when CYP1A1 mRNA expression was significantly induced after $48 \mathrm{~h}$ post exposure, the expression level of AS-hepc2 mRNA was markedly increased at this time, showing a similar expression pattern between CYP1A1 and AS-hepc2 in the liver of black porgy exposed to $1.0 \mu \mathrm{g} / \mathrm{L}$ BaP. However, unlike CYP1A1, no significant induction of hepcidin gene was observed in the other tissues tested (gill, intestine and stomach) after $6 \mathrm{~h}$, $26124 \mathrm{~h}$ and $48 \mathrm{~h}$ exposure to $1.0 \mu \mathrm{g} / \mathrm{L} \mathrm{BaP}$ (Fig. 5). It indicates that hepcidin gene is not widely expressed in tissues of black porgy upon exposure to BaP.

263 So far, knowledge regarding the effects of $\mathrm{BaP}$ on the immune system of fishes is still lacking. 264 Considering that PAHs may alter both specific and non-specific immunity in fishes and mammals 265 (Faisal and Huggett, 1993; Wolkers et al., 1998; Carlson et al., 2004), it would be worthwhile to 266 understand the ability of the immune system in fishes to deal with challenges from the external 267 environment pollutants. Studies have shown that most teleost fish immunoglobulins functionally 268 resemble the mammalian immunoglobulin $\mathrm{M}(\mathrm{IgM})$, and it is important to response against various 269 antigens (Uchida et al., 2000; Srisapoome et al., 2004). BaP can significantly alters the levels of 270 immunoglobulins in the mammalian immune system (Senthilnathan et al., 2006), but there is no related 271 report in fish. Unlike hepcidin mRNA expression, the IgL gene showed no response during continuous 272 exposure to $\mathrm{BaP}$ at three different concentrations, even up to $72 \mathrm{~h}$ post-exposure and the obvious 
expression change of IgL mRNA was only detected after $120 \mathrm{~h}$ exposure. The comparative result of gene expression patterns between hepcidin and IgL upon exposure to $\mathrm{BaP}$ suggested that the innate immune-related gene is more acute and sensitive to exposure to this pollutant than the adaptive immunerelated gene, as previously mentioned (Luster et al., 1988). However, the present result does not exclude the possibility of a short-term passive immunization exerted by the IgL. Further studies will be required to see whether IgL mRNA expression induced by $\mathrm{BaP}$ would contribute to the specific humoral defence of offspring during early development in fishes.

Our studies demonstrated that the target hepcidin gene (PM-hepc and AS-hepc2) expression was markedly induced in the fry stage of red sea bream and in juvenile black porgy upon exposure to the typical environmental pollutant $\mathrm{BaP}$ at concentrations of $0.5 \mu \mathrm{g} / \mathrm{L}$ and $1.0 \mu \mathrm{g} / \mathrm{L}$. To our knowledge, this finding has not been reported in previous studies on hepcidin expression in vivo. It is well known that hepcidin gene expression can increase to a high level in response to bacterial infection (Krause et al., 2000; Park et al., 2001; Shike et al., 2002), iron overload (Pigeon et al., 2001) and inflammation (Nemeth et al., 2003). Even more in Atlantic salmon and in black porgy, the hepcidin transcripts could be detected in tissues under normal culture conditions (Douglas et al., 2003; Yang et al., 2007). Until now, there is no evidence available on hepcidin gene expression induced in fish by $\mathrm{BaP}$ exposure. However, AhR-dependent or -independent TCDD-responsive genes have been demonstrated to change expression upon exposure to pollutants (Puga et al., 2000; Frueh et al., 2001; Kurachi et al., 2002; Adachi et al., 2004; Volz et al., 2005). Moreover, an antimicrobial peptide defensin gene level was induced highly, up to 9.76-fold of BaP-exposed Mytilus edulis (Brown et al., 2006). In addition, it is also noteworthy that the immune response related gene hepcidin precursor significantly higher transcribed in TCDD-exposed liver of Male Japanese Medaka by analysis of cDNA array (Oryzias latipes) (Volz et al., 2005). The present study demonstrated that $\mathrm{BaP}$ induced higher expression of the PM-hepc and AShepc2 transcripts in the developmental stages of red sea bream and in juvenile black porgy (Fig. 2; Fig. 5) respectively, and also AS-hepc2 mRNA was highly expressed in the liver of juvenile black porgy exposed to $1.0 \mu \mathrm{g} / \mathrm{L} \mathrm{BaP}$ (Fig. 5). These results prompted us to hypothesize that the highly enhanced 
expression of hepcidin induced by the environmental pollutant $\mathrm{BaP}$ might be a positive response related to an innate immune function as referred to one of many aspects of innate host defenses associated with an acute inflammation (Hancock and Diamond, 2000). This kind of response caused by exposure to BaP might be involved in immune- and/or inflammation-related pathways as described in TCDD-exposed medaka liver (Volz et al., 2005). In fishes, the innate immune response has been considered an essential component in host defense against pathogenic organisms due to an undeveloped adaptive immune response (Magnadottir, 2006). Current opinion tends towards a more complex view of the immune system as a sophisticated, complex, multilevel network of various defensive mechanisms (Danilova, 2006). The acute response of hepcidin to opposing exogenous pollutants may act as a signal to provide an early warning to the adaptive immune system of fishes to mount a response (Fearon and Locksley, 1996; Carroll and Prodeus, 1998) against invading pathogens or inner existing pathogenic microorganisms which might be robust enough to cause infection when the health of a BaP-exposed fish becomes worse. Taken together, the role of fish hepcidin might extend its functions to more than a key regulator of iron absorption and a mediator of inflammation (Ganz, 2003). It is known that the increased hepcidin expression induced by both bacterial challenge and iron overload were thought to be important in the host response to pathogens, however, whether the increased hepcidin expression induced by BaP is involved in the host defense against invading microorganism needs to be more clearly defined. A comparative study on hepcidin expression in bacteria-challenged fish exposed to $\mathrm{BaP}$ is ongoing following this work.

\section{Conclusion}

To our knowledge, this is the first report of PM-hepc expression significantly induced in the fry stage of red sea bream and AS-hepc2 in juvenile black porgy with exposure to the environmental pollutant BaP. This study suggested that fishes surviving in the complex marine environment might develop multi-functions to maintain their health and the antimicrobial peptide hepcidin might be one of the principal actors involved in innate immunity in responding to various exogenous factors, and thus to 
325 play their roles either directing the host acute phase inflammatory response or participating in an

326 antimicrobial defense mechanism. Further exploration of the role of fish hepcidin after exposure to BaP 327 will be focus on whether increasing levels of hepcidin transcripts could exert an immune response 328 against bacterial invading or infection that may provide new insights into the molecular mechanisms of 329 hepcidin.

\section{Acknowledgements}

This work was supported by grants (2003I005; 2007I0022) from Fujian Science and Technology Department, a grant (2007AA091406) from the National High Technology Research and Development Program of China (863 Program). We thank Professor John Hodgkiss for assisting in the preparation of this manuscript.

\section{References}

Adachi, J., Mori, Y., Matsui, S., Matsuda, T., 2004. Comparison of gene expression patterns between 2,3,7,8tetrachlorodibenzo-p-dioxin and a natural aryl hydrocarbon receptor ligand, indirubin. Toxicological sciences 80, 161-169.

Brown, M., Davies, I.M., Moffat, C.F., Craft, J.A., 2006. Application of SSH and a macroarray to investigate altered gene expression in Mytilus edulis in response to exposure to benzo[a]pyrene. Marine Environmental Research 62, 128-135.

Buhl, K.J., Hamilton, S.J., 1991. Relative sensitivity of early life stages of Arctic grayling, coho salmon, and rainbow trout to nine inorganics. Ecotoxicology and Environmental Safety 22, 184-197.

Carlson, E.A., Li, Y., Zelikoff, J.T., 2004. Benzo[a]pyrene-induced immunotoxicity in Japanese medaka (Oryzias latipes): relationship between lymphoid CYP1A activity and humoral immune suppression. Toxicology and applied pharmacology 201, 40-52. 
Carroll, M.C., Prodeus, A.P., 1998. Linkages of innate and adaptive immunity. Current Opinion in Immunology 10, 36-40.

Danilova, N., 2006. The evolution of immune mechanisms. Journal of Experimental Zoology Part B: Molecular and

Developmental Evolution 306B, 496-520.

Davila, D.R., Romero, D.L., Burchiel, S.W., 1996. Human T cells are highly sensitive to suppression of mitogenesis by polycyclic aromatic hydrocarbons and this effect is differentially reversed by alpha-naphthoflavone. Toxicology and applied pharmacology 139, 333-341.

Del Castillo, C.E., Corredor, J.E., Morell, J.M., 1992. Accumulation and depuration of hydrocarbons in the Mangrove oyster Crassostrea rhizophorae. International conference on shellfish depuration N², Rennes, France, pp. 93-99.

Denslow, N.D., Kocerha, J., Sepúlveda, M.S., Gross, T., Holm, S.E., 2004. Gene expression fingerprints of largemouth bass (Micropterus salmoides) exposed to pulp and paper mill effluents. Mutation Research 552, 19-34.

Douglas, S.E., Gallant, J.W., Liebscher, R.S., Dacanay, A., Tsoi, S.C., 2003. Identification and expression analysis of hepcidin-like antimicrobial peptides in bony fish. Developmental and comparative immunology 27, 589-601.

Faisal, M., Huggett, R.J., 1993. Effects of polycyclic aromatic hydrocarbons on the lymphocyte mitogenic responses in spot, Leiostomus xanthurus. Marine Environmental Research 35, 121- 124.

Fearon, D.T., Locksley, R.M., 1996. The instructive role of innate immunity in the acquired immune response. Science $272,50-54$

Filby, A.L., Santos, E.M., Thorpe, K.L., Maack, G., Tyler, C.R., 2007. Gene expression profiling for understanding chemical causation of biological effects for complex mixtures: A Case Study on Estrogens. Environmental science and technology 41, 8187-8194.

Frueh, F.W., Hayashibara, K.C., Brown, P.O., Whitlock, J.P., 2001. Use of cDNA microarrays to analyze dioxin-induced changes in human liver gene expression. Toxicology letters 122, 189-203.

Ganz, T., 2003. Hepcidin, a key regulator of iron metabolism and mediator of anemia of inflammation. Blood 102, 783788.

Goksøeyr, A., Solberg, T.S., Serigstad, B., 1991. Immunochemical detection of cytochrome P4501A1 induction in cod larvae and juveniles exposed to a water soluble fraction of North Sea crude oil. Marine pollution bulletin 22, $122-127$. 
Hancock, R.E.W., Diamond, G., 2000. The role of cationic antimicrobial peptides in innate host defences. Trends in microbiology 8, 402-410.

Holladay, S.D., Smith, S.A., Besteman, E.G., Deyab, A.S.M.I., Gogal, R.M., Hrubec, T., Robertson, J.L., Ahmed, S.A., 1998. Benzo[a]pyreneinduced hypocellularity of the pronephros in tilapia (Oreochromis niloticus) is accompanied by alterations in stromal and parenchymal cells and by enhanced immune cell apoptosis. Veterinary immunology and immunopathology 64, 69-82.

Hu, X., Camusb, A.C., Aono, S., Morrison, E.E., Dennis, J., Nusbaum, K.E., Judd, R.L., Shi, J., 2007. Channel catfish hepcidin expression in infection and anemia. Comparative Immunology, Microbiology and Infectious Diseases 30, 55-69.

Kennedy, C.J., Walsh P.J., 1994. The effects of temperature on the uptake and metabolism of benzo[a]pyrene in isolated gill cells of the gulf toadfish, Opsanus beta. Fish Physiology and Biochemistry 13, 93-103.

Krause, A., Neitz, S., Magert, H.J., Schulz, A., Forssmann, W.G., Schulz-Knappe, P., Adermann, K., 2000. LEAP-1, a novel highly disulfide-bonded human peptide, exhibits antimicrobial activity. FEBS Letters 480, 147-150.

Kurachi, M., Hashimoto, S., Obata, A., Nagai, S., Nagahata, T., Inadera, H., Sone, H., Tohyama, C., Kaneko, S., Kobayashi, K., Matsushima, K., 2002. Identification of 2,3,7,8-tetrachlorodibenzo- $p$-dioxin-responsive genes in mouse liver by serial analysis of gene expression. Biochemical and Biophysical Research Communications 292, 368-377.

Larkin, P., Folmar, L.C., Hemmer, M.J., Poston, A.J., Denslow, N.D., 2003. Expression profiling of estrogenic compounds using a sheepshead minnow cDNA macroarray. Environmental Health Perspectives 111, 839-846.

Livak, K.J., Schmittgen, T.D., 2001. Analysis of relative gene expression data using real-time quantitative PCR and the $2^{-}$ $\Delta \Delta \mathrm{CT}$ method. Methods 25, 402-408.

Luster, M.I., Munson, A.E., Thomas, P.T., Holsapple, M.P., Fenters, J.D., White, K.L., Lauer, L.D., Germolec, D.R., Rosenthal, G.J., Dean, J.H., 1988. Methods evaluation: Development of a testing battery to assess chemical-induced immunotoxicity: National Toxicology Program's guidelines for immunotoxicity evaluation in mice. Fundamental and Applied Toxicology 10, 2-19.

Magnadottir, B., 2006. Innate immunity of fish (overview). Fish and Shellfish Immunology 20, 137-151.

Maskaoui, K., Zhou, J.L., Hong, H.S., Zhang, Z.L., 2002. Contamination by polycyclic aromatic hydrocarbons in the Jiulong River Estuary and Western Xiamen Sea, China. Environmental Pollution 118, 109-122. 
Miller, K.A., Addison, R.F., Bandiera, S.M., 2004. Hepatic CYP1A levels and EROD activity in English sole:

biomonitoring of marine contaminants in Vancouver Harbour. Marine Environmental Research 57, 37-54.

Miller, M.R., Hinton, D.E., Stegeman, J.J., 1989. Cytochrome P450E induction and localization in gill pillar (endothelial) cells of scup and rainbow trout. Aquatic toxicology 14, 307-322. anemia of inflammation, is a type II acute-phase protein. Blood 101, 2461-2463.

Park, C.H., Valore, E.V., Waring, A.J., Ganz, T., 2001. Hepcidin, a urinary antimicrobial peptide synthesized in the liver. Journal of biological chemistry 276, 7806-7810.

412 Puga, A., Maier, A., Medvedovic, M., 2000. The transcriptional signature of dioxin in human hepatoma HepG2 cells. 413 Biochemical pharmacology 60, 1129-1142.

414 Senthilnathan, P., Padmavathi, R., Banu, S.M., Sakthisekaran, D., 2006. Enhancement of antitumor effect of paclitaxel in 415 combination with immunomodulatory Withania somnifera on benzo(a)pyrene induced experimental lung cancer. Chemico416 Biological Interactions 159, 180-185.

$269,2232-2237$.

Smith, D.A., Schurig, G.G., Smith, S.A., Holladay, S.D., 1999. The hemolytic plaque-forming cell assay in tilapia

(Oreochromis niloticus) exposed to benzo[a]pyrene: enhanced or depressed plaque formation depends on dosing schedule. Toxicology Mechanisms and Methods 9, 57-70.

Srisapoome, P., Ohira, T., Hirono, I., Aoki, T., 2004. Genes of the constant regions of functional immunoglobulin heavy chain of Japanese flounder, Paralichthys olivaceus. Immunogenetics 56, 292-300.

Stegeman, J.J., Kloepper-Sams, P.J., 1987. Cytochrome P-450 isozymes and monooxygenase activity in aquatic animals. Environmental Health Perspectives 71, 87-95. 
Stegeman, J.J., Schlezinger, J.J., Craddock, J.E., Tillitt, D.E., 2001. Cytochrome P450 1A expression in midwater fishes: potential effects of chemical contaminants in remote oceanic zones. Environmental Science and Technology 35, 54-62.

Uchida, D., Hirose, H., Chang, P.K., Aranishi, F., Hirayabu, E., Mano, N., Mitsuya, T., Prayitno, S.B., Natori, M ., 2000.

Characterization of Japanese eel immunoglobulin M and its level in serum. Comparative Biochemistry and Physiology Part

B $127,525-532$.

Van Veld, P.A., Westbrook, D.J., Woodin, B.R., Hale, R.C., Smith, C.L., Hugget, R.J., Stegeman, J.J., 1990. Induced cytochrome P-450 in intestine and liver of spot (Leiostomus xanthurus) from a polycycic aromatic hydrocarbon contaminated environment. Aquatic Toxicology 17, 119-131.

Van Veld, P.A., Vogelbein, W.K., Cochran, M.K., Goksoyr, A., Stegeman, J.J., 1997. Route-specific cellular expression of cytochrome P4501A (CYP1A) in fish (Fundulus heteroclitus) following exposure to aqueous and dietary benzo[a]pyrene.

437 Toxicology and Applied Pharmacology 142, 348-359.

438 Volz, D.C., Bencic, D.C., Hinton, D.E., Law, J.M., Kullman, S.W., 2005. 2,3,7,8-tetrachlorodibenzo-p-dioxin (TCDD) 439 induces organ-specific differential gene expression in male Japanese Medaka (Oryzias latipes). Toxicological Sciences 85, $572-584$.

White, K.L., 1986. An overview of immunotoxicology and carcinogenic polycyclic aromatic hydrocarbons. Environmental Carcinogen Review C4, 163-202.

Wolkers, J., Jørrgensen, E.H., Nijmeijer, S.M., Witkamp, R.F., 1998. Dose and time dependency of cytochrome P4501A induction in liver and kidney of B(a)P exposed Arctic Charr (Salvelinus alpinus). Marine Environmental Research 46, 117120.

Yang, M., Wang, K.J., Chen, J.H., Qu, H.D., Li, S.J., 2007. Genomic organization and tissue-specific expression analysis 


\section{Legends}

Fig. 1. Real-time PCR assay of CYP1A1 mRNA expression induced in the developmental stages

from embryos to fry of red sea bream upon continuous waterborne exposure to BaP. (a) CYP1A1 mRNA expression change in embryos at 48 hours post fertilization (hpf); The control (healthy embryos) without $\mathrm{BaP}$ exposure at $48 \mathrm{hpf}$ is used as a calibrator for analysis of CYP1A1 mRNA expression and

the bars represent the fold expression levels compared to the 18S gene. (b) CYP1A1 mRNA expression changes in fry at 24,72 and 120 hours post hatch (hph), respectively. The data was normalized corresponding to the control (unexposed fish) at each time of exposure, respectively. Error bars represent mean standard deviation. (insert line 158) (insert line 176)

Fig. 2. Real-time PCR assay of hepcidin mRNA expression induced in the developmental stages from embryo to fry of red sea bream upon continuous waterborne exposure to three concentrations of BaP. (a) PM-hepc mRNA expression change in embryos at $48 \mathrm{hpf}$; (b) PM-hepc mRNA expression changes in fry at 24, 72 and $120 \mathrm{hph}$, respectively. The control (healthy embryos) without BaP exposure at $48 \mathrm{hpf}$ is used as a calibrator for analysis of PM-hepc mRNA expression and the bars represent the fold expression levels compared to the $18 \mathrm{~S}$ gene. The data was normalized corresponding to the control (unexposed fish) at each time of exposure, respectively. Error bars represent mean standard deviation.

Fig. 3. Correspondence of the gene expression patterns between CYP 1A1 and hepcidin in the developmental stages from embryo to fry of red sea bream upon continuous waterborne exposure to three concentrations of BaP. (insert line 176)

Fig. 4. Real-time PCR assay of CYP1A1 mRNA expression in various tissues (stomach, intestine, 
$477 \mathrm{BaP}$. The data was normalized corresponding to the control (unexposed fish) at each time of exposure,

478 respectively. Error bars represent mean standard deviation. (insert line 203-204)

479 Fig. 5. AS-hepc2 mRNA expressions in liver juvenile black porgy upon continuous waterborne 480 exposure to $1 \mu \mathrm{g} / \mathrm{L} \mathrm{BaP}$ analyzed using real-time PCR. Error bars represent mean standard deviation. $481 \quad$ (insert line 223)

482 Fig. 6. Bioaccumulation of $\mathrm{BaP}$ in the liver of juvenile black porgy upon continuous waterborne 483 exposure to $1 \mu \mathrm{g} / \mathrm{L} \mathrm{BaP}$. Error bars represent mean standard deviation. (insert line 223)

484 Table 1. Primers and TaqMan probes developed in this study. (insert line 135) 


\section{Table 1}

486

Genes Primers (Forward and Reverse)/Probes

Accession $\left(5^{\prime}-3^{\prime}\right)$

number

F: ACAAAGGGCAGGGACTTAATCA

$18 S$

R: TCCCATGAACGAGGAATTCC

AB259837

P: CGCGAGCTTATGACCCGCGC

F: GCCGATGGCAGCTTTGAC

CYP1A1

R: GCACATGCCACAGATCACATT

EU163982

P: CTTCCGCCACATTGTCGTCTCCG

F: TGGAAGATGCCGTATAACAACAGA

Hepcidin

R: CCTAACATGATTGGATGTGGTGTC

AY557619

P: CCCTGCTGGCTGTCGCTTTTGC

F: CCAGAGGTCAGTACACAGTGACTCA

IgL R: GTGGTAGCTGCTAAAATAAACGTTCT

AY190706

P: CCCTGCTGGCTGTCGCTTTTGC 
488 Figure 1

489
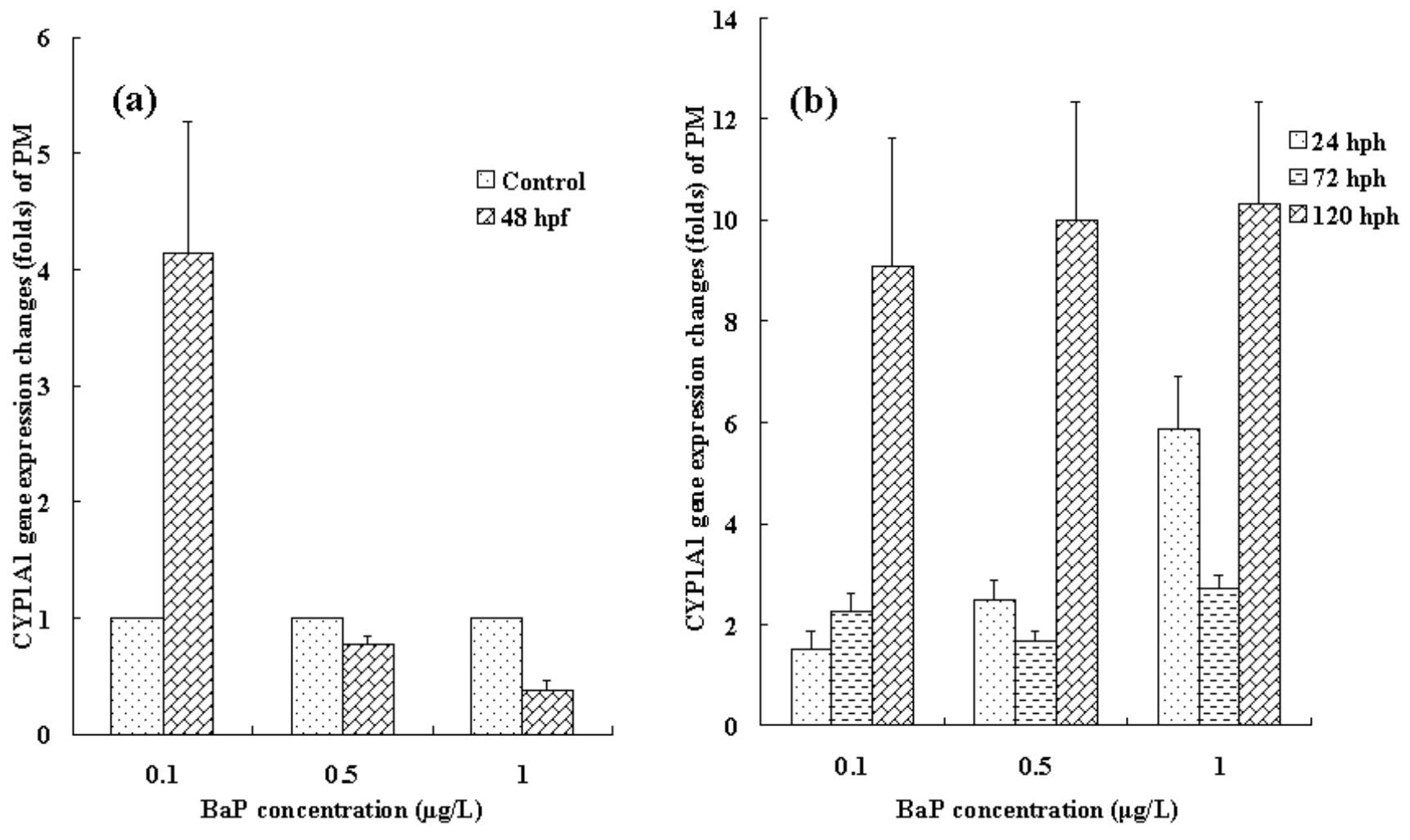
Figure 2

492
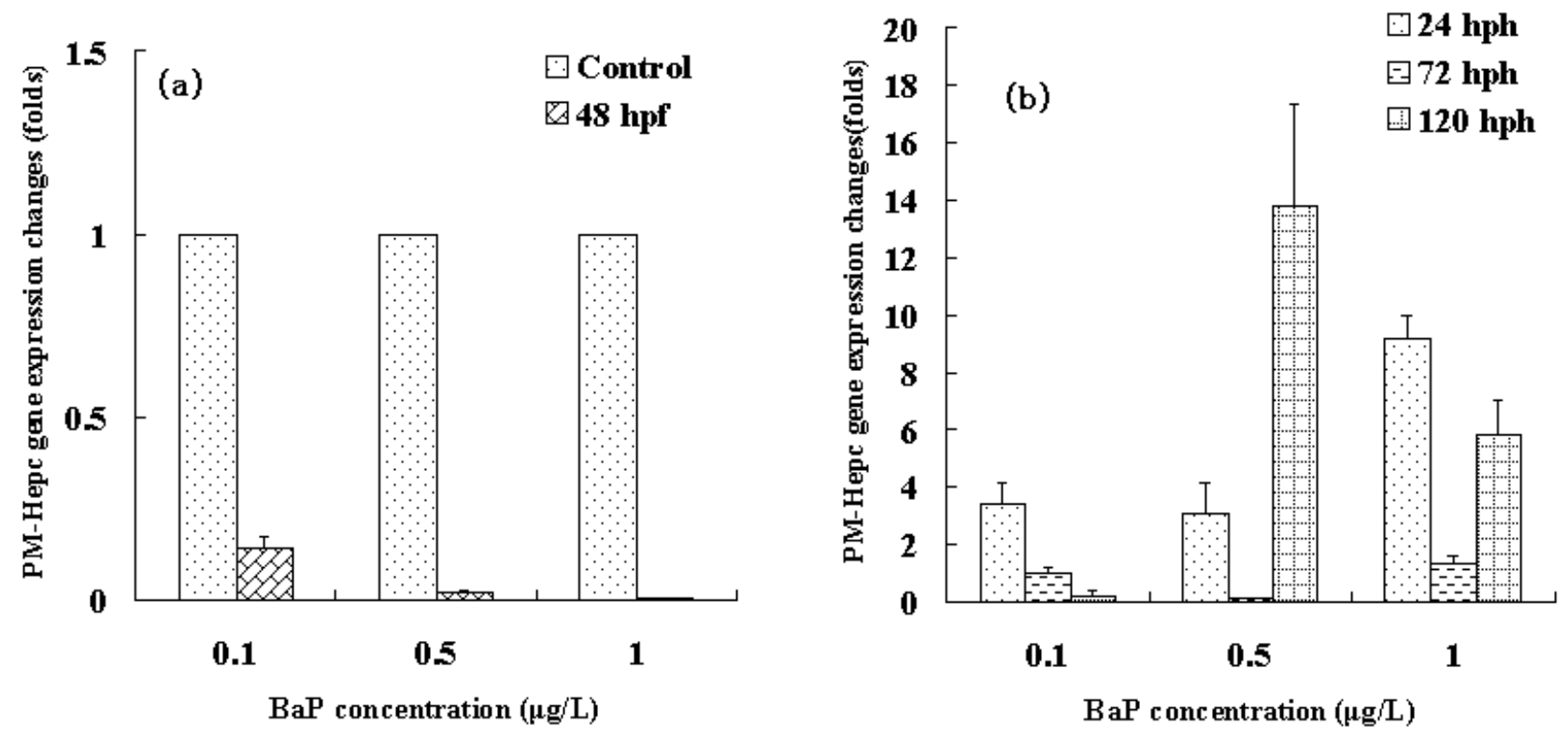
$494 \quad$ Figure 3

495

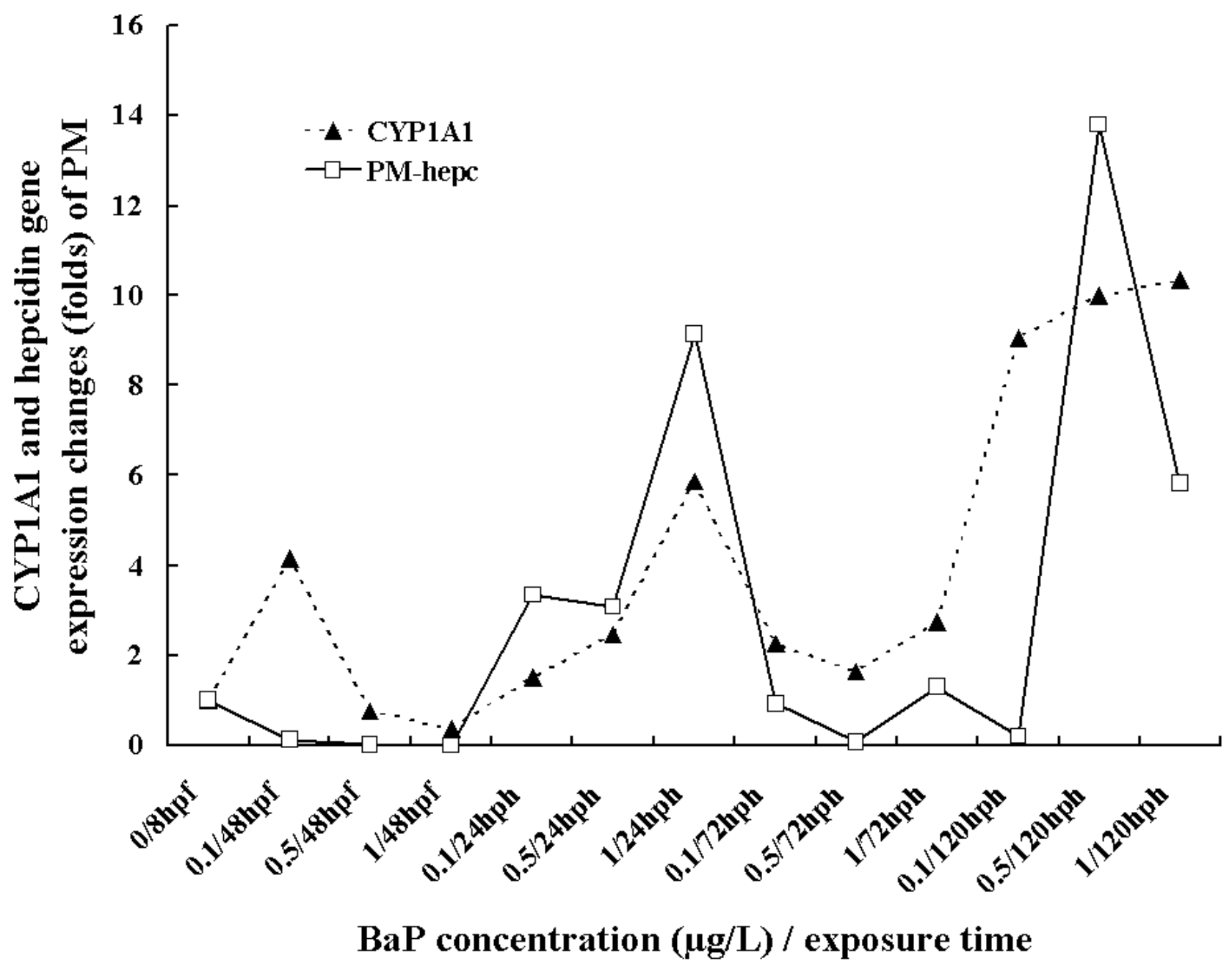

496 
$497 \quad$ Figure 4

498

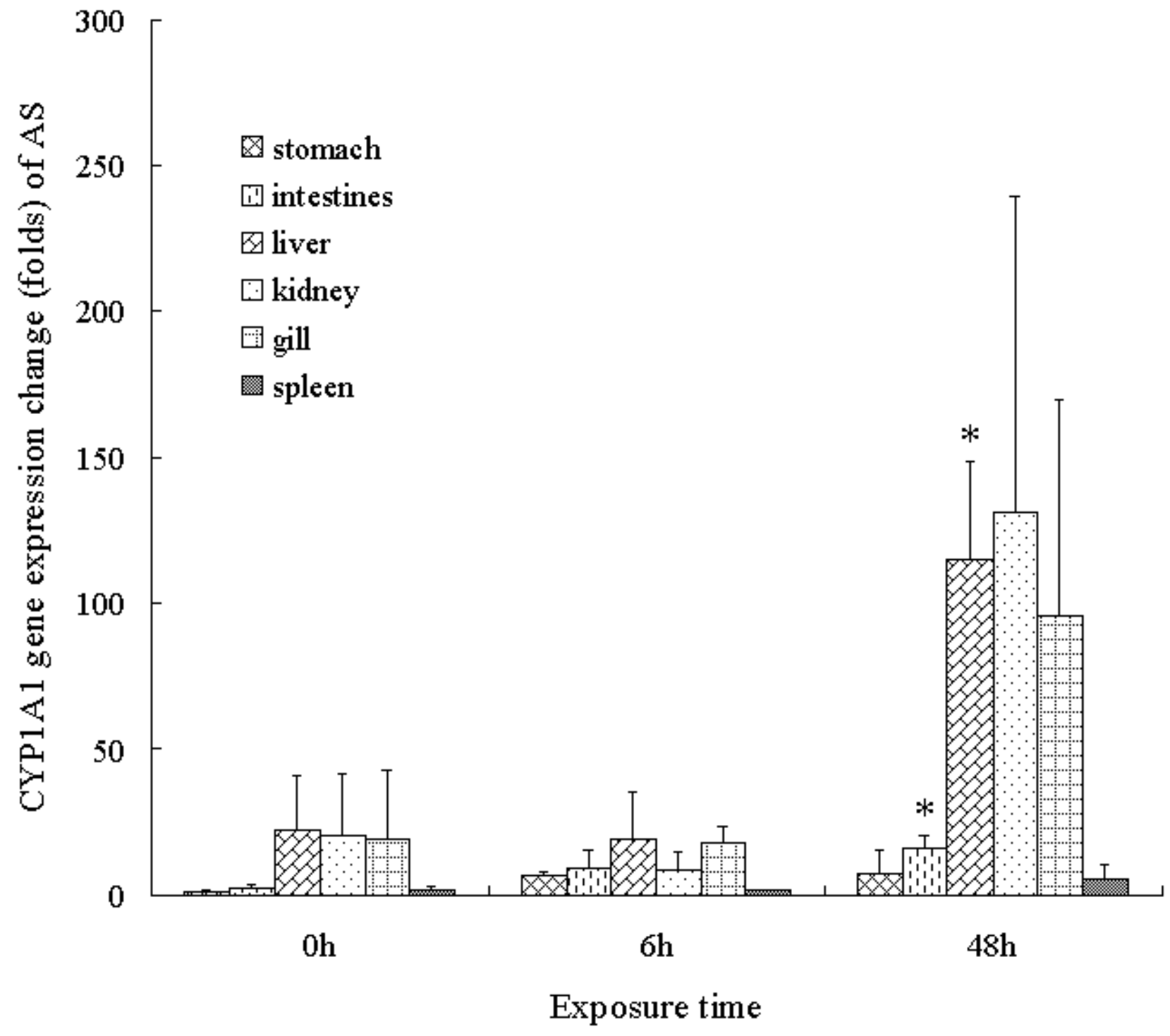


$500 \quad$ Figure 5

501

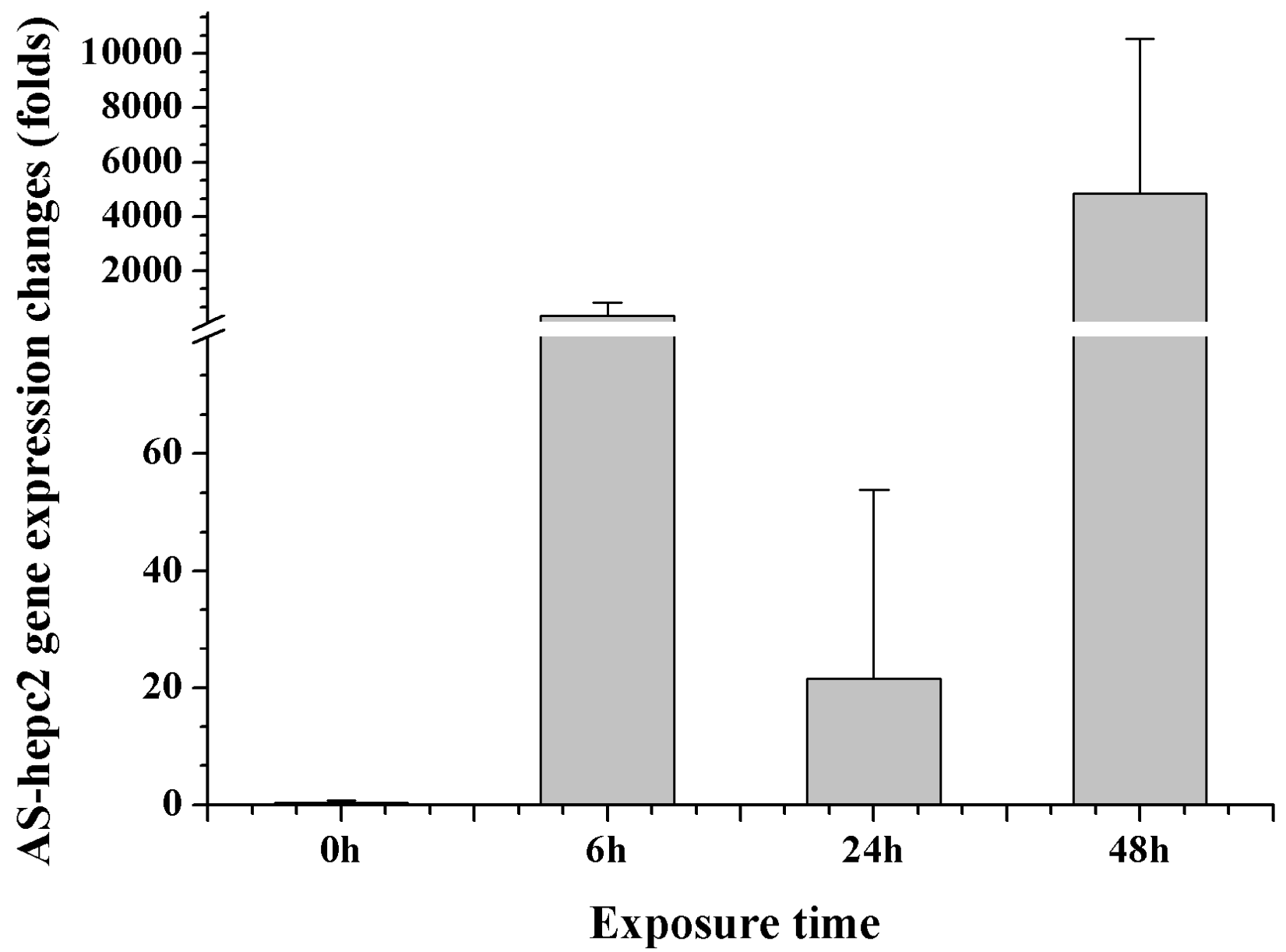

502 
$503 \quad$ Figure 6

504

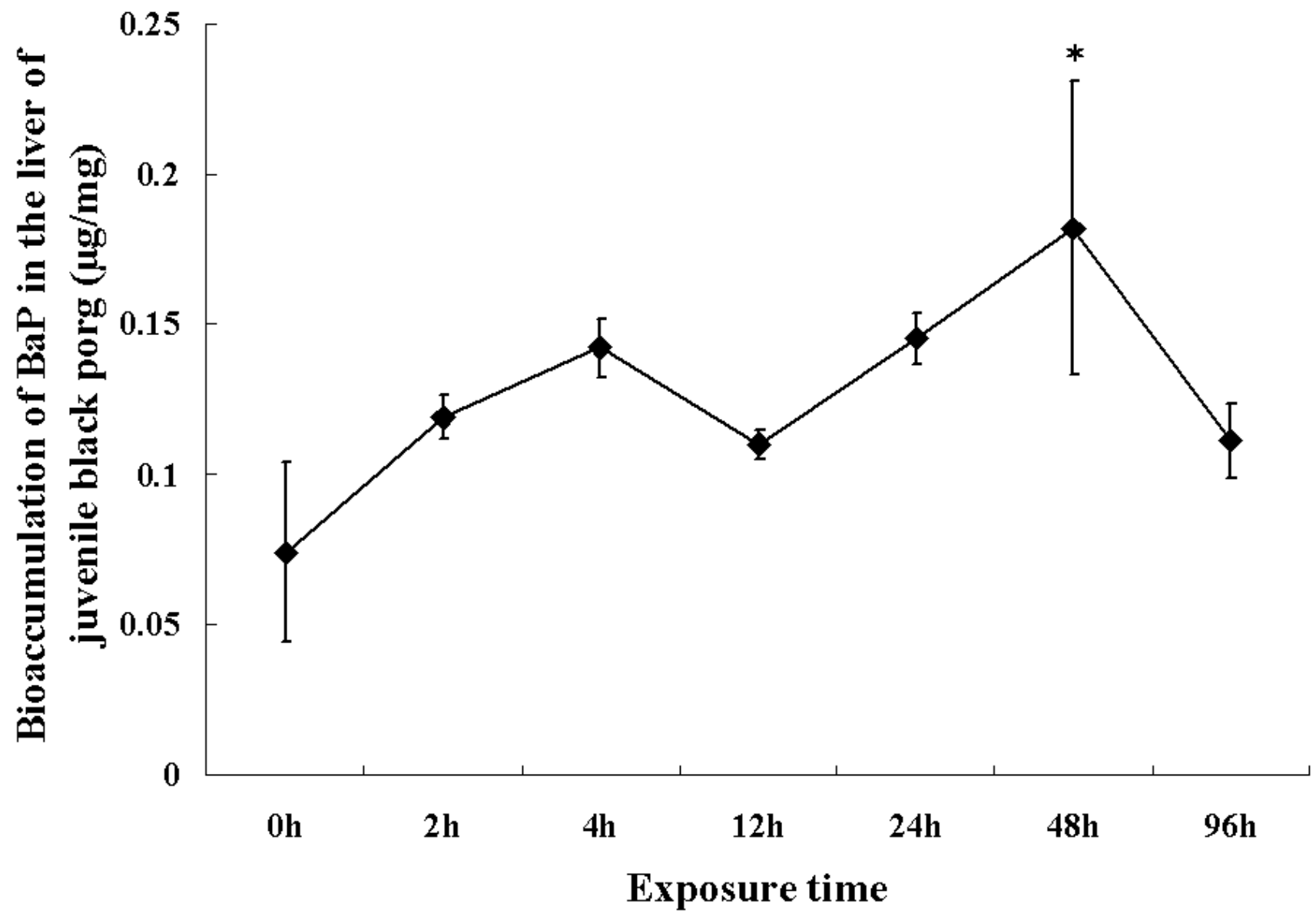

